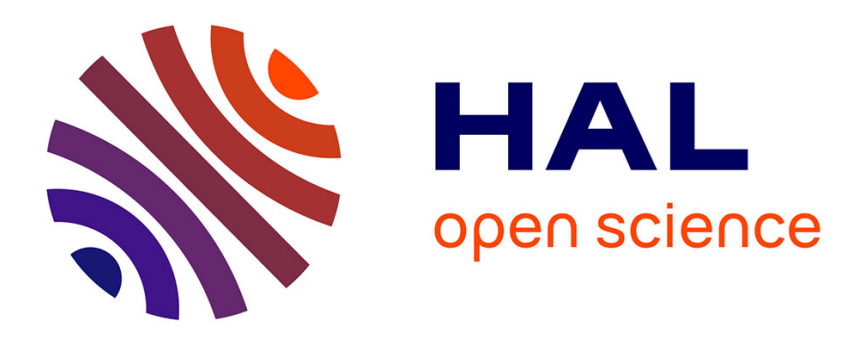

\title{
LMCTEP: software for crystal-structure representation
} Alain Soyer

\section{To cite this version:}

Alain Soyer. LMCTEP: software for crystal-structure representation. Journal of Applied Crystallography, 1993, 26 (3), pp.495. 10.1107/S0021889892010343 . hal-01214826

\section{HAL Id: hal-01214826 \\ https://hal.science/hal-01214826}

Submitted on 5 Nov 2015

HAL is a multi-disciplinary open access archive for the deposit and dissemination of scientific research documents, whether they are published or not. The documents may come from teaching and research institutions in France or abroad, or from public or private research centers.
L'archive ouverte pluridisciplinaire HAL, est destinée au dépôt et à la diffusion de documents scientifiques de niveau recherche, publiés ou non, émanant des établissements d'enseignement et de recherche français ou étrangers, des laboratoires publics ou privés. 


\section{Computer Program Abstracts}

The category Computer Program Abstracts provides a rapid means of communicating up-to-date informa. tion concerning both new programs or systems and significant updates to existing ones. Following normal submission, a Computer Program Abstract will be reviewed by one or two members of the $\mathrm{IUCr} C \mathrm{Com}$. mission on Crystallographic Computing It should not mission on Crystallographic Computing. It should no exceed 500 words in length and should use the stan of the Journal [ J Appl. Cryst (1985) 18, 189-190].

\section{J. Appl. Cryst. (1993). 26, 495}

LMCTEP: software for crystalstructure representation. By ALAIN SOYER, Laboratoire de Minéralogie-Cristallographie,

Unité associée au CNRS 09, Université Paris VI et Paris VII, Tour 16. Case 115, 4 place Jussieu. 75252 Paris CEDEX05, France

(Received 29 September 1992; accepted 2 October 1992)

The crystallographic problem: This software is intended for the space-filling representation of crystal structures. The first version (Soyer \& Rimsky, 1992) did not have facilities for the extraction of data from a crystallographic information file (CIF) (Hall, Allen \& Brown, 1991) or for the display of results on an $\mathrm{X}$-Window terminal. The purpose of this Abstract is to announce a new version in which these facilities are available.

The software consists of two parts. The main part contains four mandatory programs and three utility programs. The second part consists of versions for $\mathrm{X}$-Window terminals.

Mandatory programs. GENER4 generates atomic positions in the cell starting from the asymmetric unit and the generator symmetry elements of the space group. ORTHON computes the contents of a 'piece' of crystal, with bonds if desired. LMCTEP computes a realistic shaded color image in true perspective, with spheres or ellipsoids representing atoms and cylinders representing bonds. COLORT is a small program that creates RGB color maps for the images.

Utility programs. UTIPDB extracts data from a Protein Data Bank file for visualization of the protein with $\angle M C T E P$. UTILMC reads a list of atoms and creates data files for visualization with LMCTEP. UTICIF extracts data from a CIF (see below).

The second part. AFFICH is a simple program that displays an image, calculated by $L M C T E P$ using a color map created by COLORT, on an X-Window color display. XMAFFICH displays several images, calculated by $L M C T E P$ using color maps created by COLORT. on an X-Window color display. $X L M C T E P$ is a full integrated version for $X$-Window terminals (see below).

Method of solution:The first version of the software has been described in detail (Soyer \& Rimsky, 1992). Small modifications in the data-file format have now been made and some bugs have been removed. Two additional programs are available.

UTICIF. This is a utility program that extracts data from a crystallographic information file and creates the data files needed by our software: these files are filled with reasonable default values and may be modified later by means of a text editor.

$X L M C T E P$. This large program involves an OSF-Motif menu interface. Instead of creating data files with an editor and executing the programs sequentially, the user clicks on buttons and moves sliders with a mouse to choose options and values. All sequences that previously involved the mandatory programs are initiated from the menu. This program, written in $\mathrm{C}$, is designed for Unix workstations and $X$-Window color displays

Software environment: The main part of the software, written in Fortran77, is normally system independent and needs no extra software. The additional part, written in $\mathrm{C}$, runs under Unix with the $X$-Window system and OSF-Motif widgets, so the Xlib, $X t \mid n t r i n s i c$ and $X m$ libraries are mandatory.

Hardware environment: The software runs on a Hewlett-Packard $9000 / 370$ workstation (HP). The Fortran part is portable onto any computer that can address about 2 Mbytes of memory. A color screen with a depth of 8 bits (or more) is necessary to display the calcuated image. The part of the program written in C needs more memory: 8 Mbytes are recommended.

Program specifications: Examples of run times have been given elsewhere (Soyer \& Rimsky, 1992); note that modern RISC workstations are five to ten times as fast as our old HP. The volume of the source code can be estimated at 8000 lines (including commentaries), for both the Fortran and the $\mathrm{C}$ parts.

Documentation: The documentation of the first version was very brief and was incomplete. A new one, of about 700 lines, which describes the software organization, the installation procedure and the use of the main programs is now available in the form of an ASCII file. It contains sample data files and a listing of a typical execution.
Availability: This software is available on request from the author, whose email address is soyer (almcp.jussieu.fr. The provision includes all source code, documentation and an example of some data files, and the preferred method of distribution is by email. If this is not possible, a 3.5 in MS-DOS diskette should be sent. Distribution is free of charge to the research and teaching communities

Keywords: Crystal-structure representation, thermal ellipsoid, realistic synthetic image, CIF.

\section{References}

Hall, S. R., Allen, F. H. \& Brown, I. D. (1991). Acta Cryst. A47, 655-685 Soyer, A. \& Rimsky, A. (1992). J. Appl. Cryst. 25, 214-220. 